\title{
The Mimetic Basis of Pure Music in Machaut's Refrain Songs:
}

\section{Part 2, Musical Abstraction}

\author{
David Maw*
}

ABSTRACT: The dualistic relationship of words and music in Machaut's refrain songs (proposed in Part 1 of this article) enables abstraction of the music from the poetic model that inspired it. This situation is at its most extreme in certain rondeaux, representatives of a genre for which a special function in Machaut's output is argued. Studies of specific groups of songs (B9-R4 and B35-R13R21) illustrate the gradual development and detachment of material in related compositions. Through these accounts, it can be seen that the relationship of words and music proceeds on the same fundamental basis in the seemingly melismatic rondeaux as in the syllabic virelais, despite the apparently closer connection found in these latter. The technical unity at work in Machaut's song composition is constitutive of an aesthetic position. The abstracted musical text is an aspect of the multi-faceted voice of Machaut's lyric cuvre and tends to subsume the poetry it sets creating an aesthetic of pure music.

\section{The rondeau as site for autonomous musical thought}

Although declamatory rhythm forms a structural basis of song composition in all three of the refrain genres, there is a marked diversity between the genres in the extent of the music that arises in response to the initial poems. The range of this diversity can be seen by comparing the syllable-tobreve ratio (the number of syllables in the poem against the number of breves in the music, counting each part just once) of each song. In the virelais, it varies between 58:16 (for 'Dame, a vous' [RF6]) and 40:28 (for 'Quant je sui' [V13]), meaning that it is not uncommon to encounter as many as four syllables to the breve, and rare that a syllable should last longer than a breve. The ballades offer a wide range of values, from those in which there is relatively little music proportionate to the syllables - 'Ma chiere dame' (B40) has a ratio of 68:32, similar to those of the virelais - through a rough parity to those in which the music exceeds the syllables - ' $S$ 'Amours ne fait' (B1) has a ratio of 50:78. ${ }^{1}$ For the rondeaux, however, the ratios show a bias very clearly towards the music.

\footnotetext{
*david.maw@oriel.ox.ac.uk

Completion of the work was aided by a Leverhulme Trust Research Fellowship for the academic year 2018-19. Translations are my own. Music examples derive from my edition of Machaut's works which can be accessed at: www.machautedition.wordpress.com I am grateful to Catherine Bradley and David Lee for their assistance with the musical examples.
} 
Exceptionally, the relationship of words and music in R1 is just shy of parity (14:12); but in most cases music greatly overwhelms the poem, with R14 representing an extreme (16:80).

The markedly greater emphasis of the music in the rondeaux suggests that this genre served a different function from the others. In part, its history may account for this. Whereas the ballade and virelai were forms that only began to be distinctively cultivated during the fourteenth century and were thus part of the period's new song culture, ${ }^{2}$ the rondeau was already defined as a genre of polyphonic music by the end of the thirteenth century. It appears to have been sidelined initially in the fourteenth century. The few examples that survive show a gradual loosening of the relationship of words and music within the established formal outline. The compositional principles appear to be experimental. $^{3}$

In Machaut's work, the rondeau occupied a marginal place to begin with but gained in importance as the output developed. The version of La Louange des dames (the collection of lyric poems not set to music) that was collected in Mach-C (Paris, Bibliothèque Nationale de la France, fonds français 1586), and is thus the earliest surviving, had just 36 rondeaux, compared to 146 ballades. ${ }^{4}$ Subsequently 46 ballades were added with 18 rondeaux, showing a notable increase in the proportion of the latter genre. The genre is also less well represented in Mach-C's collection of chansons notees (see Table 1). At this early stage in his work, Machaut was engaged in the cultivation of established large-scale genres (the polyphonic motet and the monophonic lai) and the formulation or consolidation of new ones (the polyphonic ballade and monophonic virelai). The rondeau is notably less numerous than the other genres with the exception of the lai, and there the great length of the songs means that the small number of individual compositions nonetheless accounts for the largest quantity of music.

\footnotetext{
1 'Dous amis' (B6) and 'Dame, comment' (B16) have even sharper ratios (35:63 and 46:90 respectively), but these are owing to the extensive use of declamation at the modus level of rhythm that is a stylistic feature of the songs and exceptional in them (though common in the lais). Their ratios conform to the norm for the ballade (35:21 and 46:30 respectively) if the perfect long rather than the breve is counted, which is a more realistic way of assessing them. ${ }^{2}$ Lawrence Earp, 'Lyrics for Reading and Lyrics for Singing in Late Medieval France: The Development of the Dance lyric from Adam de la Halle to Guillaume de Machaut', in Rebecca A. Baltzer, Thomas Cable and James I. Wimsatt, ed., The Union of Words and Music in Medieval Poetry (Austin, 1991), 101-129; Christopher Page, 'Tradition and Innovation in BN fr. 146: The Background to the Ballades,' in Margaret Bent \& Andrew Wathey, ed., Fauvel Studies: Allegory, Chronicle, music, and Image in Paris Bibliothèque Nationale de France MS Français 146 (Oxford, 1998), 353-94.

${ }^{3}$ Mark Everist, “'Souspirant en terre estrainge": the Polyphonic Rondeau from Adam de la Halle to Guillaume de Machaut,' Early Music History, 26 (2007), 1-42, especially 33-42.

${ }^{4}$ These statistics follow Table 6.3 in Lawrence Earp, Guillaume de Machaut: A Guide to Research (New York and London, 1995), 247-55, discounting poems also set to music or regarded as of doubtful authorship.
} 


\section{[INSERT TABLE 1 AROUND HERE]}

Machaut may, then, have been unsure initially to what use the rondeau, with its exceptionally terse poetic content, could be put. ${ }^{5}$ Nonetheless, in the groups of manuscripts representing subsequent stages of his work, the genre appears in proportionally greater quantities, suggesting that it acquired a growing significance for him during the last couple of decades of his life. It exceeded the motet, lai and virelai in terms of the number of songs written, though still, of course, accounting for a substantially smaller quantity of actual music than these first two. Most significantly, it caught up with the ballade in the composer's final decade, with four each of the two forms being written, and with the final rondeau ('Quant je ne voy' [R21]) overtaking the ballades in length. ${ }^{6}$ The rondeau is thus the only genre which seems to have grown in interest for Machaut over time.

Despite the continuity of form with thirteenth-century compositional practice, Machaut's rondeaux were, with the exception of R1 and 'Puis qu'en oubli' (R18), unlike their precursors. The genre's established identity presented to fourteenth-century composers the challenge of reinvention. They sought to put the familiar pattern to new purposes. ${ }^{7}$ If the rondeau was to become a song of artistic significance, it had to be through the development of the music, given the inevitably slight extent of its poetry. There are several ways in which Machaut met this challenge, but the proposal of this article is that the techniques of mimesis and dislocation (discussed in Part 1) played a central role. There is not scope here for an exhaustive analysis; some representative examples will have to suffice.

The copy of R21 in Mach-E (Paris, Bibliothèque Nationale de la France, fonds français 9221,fol. 141r) sheds light on the matter. It lacks the contratenor found in the other source (Mach-G: Paris,

\footnotetext{
${ }^{5}$ It should be noted, though, that Machaut had to some degree answered this question by the time of the Remede de Fortune (thought to have been written in the 1340s - see Earp, 'Lyrics for Reading and Lyrics for Singing', 213 and The Ferrell-Vogüe Machaut Manuscript, DIAMM Facsimiles 5, 2 vols. (Oxford, 2004), 1:30-31), which includes a rondeau alongside the other genres in its inserted survey of lyric songs.

${ }^{6}$ The two longest rondeaux are R14 (from the 1360s) and R21 (from the 1370s), which have lengths of 80 and 76 breves respectively. The only ballade that is longer is B16, with 90 breves; but its exceptional rhythm has already been mentioned (in note 1 above), and the song does not undermine the narrative of the rondeau's advance in importance relative to the ballade. It should be noted, however, that the progress of the rondeau is not a simple linear one, as two of Machaut's last four essays in the genre represent a return to an earlier structural approach: R18 maintains a tight declamation and compact form similar to R1; 'Douce dame, tant com' (R20) has a more florid style and is longer than these but maintains a similarly tight declamation (see the reconstruction in David Maw, "Bona cadentia dictaminum": Reconstructing Word Setting in Machaut's Songs', Music and Letters, 94 (2013), 383-432, at 391-2 and 399-400). ${ }^{7}$ Jacqueline Cerquiglini-Toulet has observed that 'writers of the fourteenth century were acutely aware of living in a time of crisis in literary materials' (trans. Lydia G. Cochrane, The Color of Melancholy: The Uses of Books in the Fourteenth Century [Baltimore, 1997], 52). The Ars nova in music was in part a reaction to a similar crisis in musical materials, and the rondeau focused the anxieties to which it gave rise.
} 
Bibliothèque Nationale de la France, fonds français 22546), but the musical text is otherwise fundamentally the same. The word setting, though, is strikingly different: it begins similarly, but in Mach-E each line is repeated in the final phrase of the respective part (Example 1). Repetition of this kind does not otherwise occur in Machaut's output, and its presence in a copy that lacks the crucial contratenor voice suggests the intervention of a different creative perspective from that of the composer himself. ${ }^{8}$ This, though, is immaterial to what the copy demonstrates: that the final phrase of each part can set the respective poetic line on its own and that it was technically and stylistically appropriate for it to do so. It reveals a general truth about much of Machaut's melismatic writing, namely that its phrases are usually apt for declamatory word setting. The difference observable between the implied word setting of the music and the actual setting of the poem in B4 (discussed in Part 1 of this article), ${ }^{9}$ becomes especially pertinent when considering songs where lengthy melismas set single syllables, as often in the rondeaux. What shapes the phrases in these cases may be an imagined versification.

\section{[INSERT EXAMPLE 1 AROUND HERE]}

From this it seems that the shaping of phrases without words depends on the experience of having first shaped them with words. The work that Machaut had done in writing ballades was an important source for him in his reinvention of the rondeau. ${ }^{10}$ In that genre, the poem supplied an extensive formal outline as a scaffold on which to construct musical ideas. With the experience of writing a ballade behind him, Machaut had sufficient command of the musical materials to attempt a rondeau, where the given poetic form might comprise just ten syllables in each part. 'Sans cuer dolens' (R4) is an example of this process, employing material and structural ideas already worked in 'Dame, ne regardez pas' (B9). The material shared by the ballade and rondeau is shown in

\footnotetext{
${ }^{8}$ Mach-E is a source whose authorial status is puzzling. It is the unique source for Machaut's final two lais yet it lacks other pieces (eg Hoquetus David) from the oeuvre. Some of its copies present texts that are superior to those found in the other Machaut Music Manuscripts (eg triplum of R9, tenor of R21 - yet the textual superiority in this latter case is paradoxical as the copy is inferior for lack of the contratenor, not an optional voice here). It presents some additional voice-parts that are credible as the work of Machaut (eg contratenors of B27, R7, triplum of B31). Yet it also contains highly corrupted readings derived from Mach-B, added voice-parts that are not (or probably not) by Machaut (eg contratenors of B20, B23) and shows a dependency at times on repertory manuscripts outside Machaut's sphere. See Margaret Bent, 'The Machaut Manuscripts Vg, B and E,' Musica Disciplina 37 (1983), 53-82, especially $61-76$ and 7882. The comments on 73 are particularly salient.

${ }^{9}$ David Maw, 'The mimetic basis of pure music in Machaut's refrain songs: part 1, musical mimesis,' Plainsong and Medieval Music, 29 (2020), 27-50, at 35, 37-8.

${ }^{10}$ My proposal here is not that Machaut composed ballades before turning to the rondeau as specific phases of activity, but that there are close relationships between certain rondeaux and ballades deriving from a compositional process in which the ballades were written first. The composition of the ballades and rondeaux in these relationships may well have been temporally close.
} 
Example 2 and consists in various sections of a more-or-less fragmentary nature. The process of detaching the material from the poetic structure is in fact already begun in the ballade, which recycles phrases between lines of the poem, and thus the rondeau merely takes it a stage further. In Mach-C, the poems of both songs appear in La Louange de dames and the music-section, suggesting that they were written before musical setting was envisaged. If this was indeed the case, it is reasonable to infer that the poems offered possibilities for musical setting that Machaut was interested to explore.

\section{[INSERT EXAMPLE 2 AROUND HERE]}

The poem of B9 mixes lines of five, seven and eight syllables in its stanzaic form: a7b5 a7b5 b7c8C8. It is the only ballade that Machaut set to music with three different line-lengths and presents an unusual challenge for that reason. ${ }^{11}$ The song adopts extensive isosyllabic setting (Example 3a). ${ }^{12}$ In principle, such setting creates a direct correlation between the length of the line and that of the music setting it (as in the notional declamation of Example 3c). This is indeed the case for the first lines of the second part, the point at which the isosyllabic setting begins, as the heptasyllable receives a phrase of seven breves (see the actual declamation modelled in Example 3b). The following two lines continue the isosyllabic setting, but within this framework, the musical phrasing works independently. ${ }^{13}$ The first of them is an octosyllable and begins with an anacrusis. As it does not take time from the preceding rhyme, there is a momentary shift from duple into triple metre, jolting the metre at the change in line-length. However, the music undermines the contrast, as the line is set not as a single phrase but as two short ones, divided after the third syllable. The music adopts phrasing for a trisyllable plus a pentasyllable. As will become apparent, in doing so it echoes phrasing used earlier in the song.

\footnotetext{
${ }^{11}$ Whilst 'Dous amis' (B6) seems also to have lines of three different lengths, the shorter ones (of four and three syllables) are in fact written as complementary pairs that equal the length of the long ones (heptasyllables). In effect, it is a monometric poem in heptasyllables in which some of the lines have leonine rhyme at the fourth syllable.

${ }^{12}$ See Maw, "Bona cadential dictaminum", 404-5, 409-12, 429 and 431 for reconstruction of the word setting in these songs.

${ }^{13}$ The analyses that follow use the concept of implied declamation to explain the detachment of musical phrasing from the poetic form. An issue arises here in the recognition of phrase boundaries: the length of cadences and the treatment of anacrustic elements. For example, in the first line of B9, the anacrustic eighth breve is not counted as part of the following heptasyllable, although the same figure occurs within the phrase four breves later. In that case, the cadence is taken as lasting a long. In the second line, however, the cadence of the first pentasyllable lasts just a single breve. In the oultrepasse the two types occur one after the other (breve-cadence for the opening heptasyllable, long-cadence for the ensuing trisyllable). These inconsistencies are justified by their occurrence in the actual phrasing of Machaut's songs. In B3, the cadence of the first main phrase lasts a long (at breve 9); that of the following phrase lasts just a breve (at breve 17). Similarly, the anacrusis into the fourth phrase of B10 is included within the declamation of the line (at breve 14, "se souvent') but not into the second phrase of the second part (breve 5 of the second part, 'en vous').
} 


\section{[INSERT EXAMPLE 3a-c here; NB: Example 3a is provided as two separate files]}

The final octosyllable is set in the quasi-declamation of a heptasyllable with paroxytonic rhyme, whose stressed syllable is melismatically extended. Against this, the music consists in two heptasyllabic phrases. The reduction of the cadence of the first phrase to a single breve creates a momentary change to triple metre at the join of the two phrases, a parallel to the similar moment in the previous pair of phrases.

Despite the simple approach of the declamation in the second part, the relationship of poem to music is complex: both octosyllables are set over two phrases; and the phrasing is not predictable from the rhythm of the poetic lines (compare Examples $3 b$ and 3c). A similar complexity obtains in the first part, even though each of the two lines is set in a distinct section separated by a rest. The setting may initially appear to be melismatic, but it is in fact carefully formed. Its structural complexity derives from movement between rhythmic levels. The first line starts in the firstrhythmic mode at the maximodal level for the first four syllables before shifting into the isosyllabic fifth mode at the modus level (the same declamation as the song's second half) for the fifth and sixth syllables. The second line begins at an even higher level than the first, an imagined supramaximodal level, with two maxima creating a very long fifth-mode unit before an abrupt shift into the tempus level for the third and fourth syllables. The declamation may seem perverse, given its contrasts of syllabic rhythm; but the timespans that these declamations create enable phrasing that relates to the poetic lines being set. The first line is set to two isosyllabic heptasyllabic phrases; the second to two isosyllabic pentasyllabic phrases. The declamation is thus in each case a solution to the challenge of fitting one line to two phrases, a more interesting one than that of simply doubling the lengths of the syllables. At the repeat of the first part, the clos is made by adding an isosyllabic trisyllabic phrase into the declamation of the penultimate syllable. The phrase is very similar in its musical content to the one at the beginning of the middle line of the second part, drawing attention to the echo of phrase-lengths at that point in the song.

What emerges in the combination of poem and music in this song is a subtle counterpoint between the implied and actual versification schemes. Whilst the two share line-lengths of seven and five syllables, the music is more unified, avoiding the octosyllables and implying the first of them only through the combination of phrases of three and five syllables:

Formal part: Syllables in poetic lines:
II

$\begin{array}{lll}7 & 8 & 8\end{array}$



Syllables in implied setting:
$7-7 \quad 5-5(-3)$
$7-3-5$
7-7

The music creates a very different formal balance between its four sections from that implied by the poem:

$\begin{array}{lllll}\text { Section: } & \text { I.i } & \text { I.ii(o/c) } & \text { II.i } & \text { II.ii } \\ \text { Syllables: } & 7 & 5 & 15 & 8 \\ \text { Breves: } & 16 & 11 / 14 & 17 & 15\end{array}$

The four sections vary greatly in the number of syllables they set, but they are very close in their musical lengths. The song pursues a formal equilibrium radically different from that of the poem. The poetic rhythm of $\mathrm{B} 9$ is unusually complex; that of R4 is by contrast very simple: the refrain comprises two decasyllabic lines (A10 B10), each with a fourth-syllable caesural accent. Where in B9 the music expresses formal regularity against the irregularity of the poem, in R4 it expresses irregularity against the regularity of the poem; and it is the music of B9 that provides the model for it. Both lines of the rondeau are set as a series of shorter phrases (four in the first part and three in the second - Example 4a); and none of the phrasing relates to the decasyllabic rhythm that is the starting point in the verse. The declamation of the lines is based on an isosyllabic approach similar to that of B9, but the basic length of the syllable is the long rather than the breve (see the notional declamation of Example 4c). Within this framework, Machaut works some variation in syllabic length, most obviously at the joins of the hemistichs, where fourth and fifth syllables are contracted within the modus metre; but there is also contraction of the last syllable and extension of the seventh and eighth in the first part and contraction of the first and extension of the last two in the second part (see the actual declamation modelled in Example 4b). The starting point of each part is a duration of 12 longs, a period that remains in the first part despite the adjustments but which is contracted to 10 longs in the second part.

\section{[INSERT EXAMPLE 4a-c here]}

The debt to B9 is clear in the phrasing, which employs the heptasyllables, pentasyllables and trisyllables of that song. The only exception is the octosyllabic first phrase; but even that invokes the phrasing of B9 through an incomplete cadence at the fifth syllable, creating run-on pentasyllabic and trisyllabic phrases.

Formal part:

Syllables in poetic lines:

Syllables in implied setting:
I

$4 \quad 321$

$8(5+3) \quad 553$
II

442

755 
In B9, Machaut drew out from the poem a song that combined variety of phrasing with formal balance. The isosyllabic setting at the oultrepasse supplied a strong rhythmic framework for inventing the music, and from it the rest of the song could be derived. The contrasted line-lengths of the poem prompted Machaut to sequences of phrases of varied lengths in the celos of the first part and the oultrepasse of the second. This in turn provided a solution to the challenge of creating musical interest within the neutral rhythmic scheme of the rondeau poem of R4. Using a similar isosyllabic basis but with the syllables slowed down to change on the long, he projected on to it an independent phrase structure, using phrase successions of B9 as a model.

Comparison of the tonal design of the two songs (represented schematically in Table 2) reveals a parallel move from simplicity in the ballade to complexity in the rondeau. The ballade is firmly rooted in chords of a. The only moves away from that basis are at the clos and final cadences, which rest on $\underline{\mathrm{G}}$. The overall tonal form, a progressive one, uses rhyming closure in a similar way to the couples of the ballade poem. The $\underline{\mathrm{G}}$ chord finishing the first part seems like an open harmony because of its contrast with the prevalent a chords. It acquires a closed function through repetition at the end of the second part, where it completes the rhyme of the first part. Compositional focus on the subtle interplay of phrase lengths in this song was offset by the adoption of a simple tonal design. In drawing on this experience of handling phrase length, Machaut was able to wield a more elaborate tonal design in the rondeau, one central to the idea of the song. Although a and G chords are still the primary ingredients, there are cadences also on $\mathrm{c}$. In the first part, $\mathrm{c}$ is a varied prolongation of the a harmony; but in the second part it enables a striking move to a c'/F chord, at the word joie, a moment that broadens the tonal palette of the song. The tonal form stages a departure from and carefully paced return to the $\mathrm{g} / \mathrm{G}$ chord with which it begins. This plan invokes the lover's sorrow at leaving his lady and expectation of joy at his return to her, as recounted in the poem. ${ }^{14}$ The tonal form is thus recursive, but $\mathrm{G}$ chords are used only as a harmonic frame, not fully developed as a key centre. The subtle and quite elaborate tonal workings of this song are necessary as a response to the poem. Their realisation was facilitated by the appropriation of materials and formal ideas from the ballade.

\section{[INSERT TABLE 2 AROUND HERE]}

\footnotetext{
${ }^{14}$ Yolanda Plumley, 'The Marriage of Words and Music: Musique Naturele and Musique Artificele in Machaut's Sans cuer, dolens (R4)', in Elizabeth Eva Leach, ed., Machaut's Music: New Interpretations (Woodbridge, 2003), 231-248, at 241-3.
} 
Detachment and development of musical material were central to Machaut's technique in composing rondeaux. Detachment is an important component of what is sometimes perceived as an autonomy of musical materials in Machaut's music. ${ }^{15}$ In B9 and R4, the various common figures and sections of phrases look like part of an independent stock of musical ideas, manifestations of a particular style or subgenre perhaps (they occur also in B30 and R12). A later group of songs shows a higher order of shared material, amounting to common phrases and even sections of music, and manifests the apex of such musical autonomy in Machaut's work. Procedures are adopted and developed from ballade into rondeau and then from these two songs into another rondeau. 'Gais et jolis' (B35) and 'Dame, se vous n'avez aperceu' (R13) are both amongst the additions to the œuvre found in Manuscript Vg and are thus likely to have been composed at some point in the period c.1353-65, perhaps close to one another within that. ${ }^{16}$ Both use decasyllables and the device of the musical refrain at the end of each part.

As was observed earlier, the hemistichal structure of the decasyllables can be imitated in music by proportionate phrase length and cadential differentiation (imperfect and perfect). This decasyllabic structure can be found in the second line of the oultrepasse of B35 (Example 5); but it is the only point in the song where the poetic and musical structures are aligned. Yet the form of the decasyllable is central to the implied declamation of the music throughout; it is, though, more often detached from the poem than aligned with it (Table 3).

\section{[INSERT EXAMPLE 5 and TABLE 3 AROUND HERE]}

The phrasal form is balanced, with four phrases in each part leading to the musical refrain, also of four phrases. A four-square equilibrium is avoided by using breve declamation for the first four phrases of the first part and semibreve declamation elsewhere, giving greater weight to the first part over the second. The symmetrical arrangement of the first four phrases of the first part ${ }^{17}$ is reversed in the second part. These formally closed structures are contrasted with the progressive structure of the musical refrain, which presents the phrasing of two decasyllables in succession. In the oultrepasse, the phrases are aligned with the poetic lines. The correspondence in the second of them has already been noted; but in the first, the reversal of phrases necessitates prolonged declamation

\footnotetext{
${ }^{15}$ Karl Kügle, 'Some Observations Regarding Musico-Textual Interrelationships in Late Rondeaux by Machaut,' in Leach, ed., Machaut's Music, 263-276, especially 268-71.

${ }^{16}$ Material in these songs is also shared with R17, B32 and B33; Yolanda Plumley, The Art of Grafted Song: Citation and Allusion in the Age of Machaut (New York, 2013), 362-3.

17 The rhythm of these phrases brings out the differences of phrase-length by adding or subtracting statements of a recurrent cell (1 minim, 3 semibreves, 3 minims).
} 
for the minor hemistich and dimished declamation in minims for the major hemistich. ${ }^{18}$ The other lines, those set to the first part and to the musical refrain, are distributed across two pairs of phrases, meaning that each is set to the music for two.

As in B9, the counterpoint between the implied setting of the music and the actual setting of the poem in B35 means that the declamation of the poem comes in and out of focus with the music. Where it differs from B9 is that the musical phrases are consistently shaped around the decasyllable of the poem. The poem and music are rhythmically consistent with one another; but where the poem proceeds in a regular succession of minor and major hemistichs, the music introduces variety by reversing the order of certain hemistichs and by changing the rhythmic level of the declamation in the first part. The relationship of the words to the music is still fundamentally a close one. All the minor hemistichs are set to individual phrases, and with the sole exception of the first of the second part, these phrases are of the right sort (that is, minor-hemistich phrases). By contrast, the major hemistichs are often set melismatically over two or more phrases. The poem supplies a rhythmic model for the musical setting here, but the musical phrasing is mostly detached from it.

R13 draws on B35 to realise quite different ends. There are several echoes between the music of the two songs (Example 6, i-iii): two near quotations (6, i, ii); and the sequential minor hemistich phrases in the first part $(4,5 \text { and } 6)^{19}$ use the retrograde version of the rhythmic cell from the opening phrases of B35, accompanied by the same semibreve-breve-semibreve figure in the tenor $\left(6\right.$, iii). ${ }^{20}$ The song resembles B35 also in setting two lines in its first part, one of just three rondeaux to do so. ${ }^{21}$ Table 4 presents the scheme of R13.

\section{[INSERT EXAMPLE 6 AND TABLE 4 AROUND HERE]}

The first line is set to two hemistichs, the normal arrangement found in the second part of B35, but developed here by changing the rate of declamation between the two hemistichs. The second line follows the pattern of B35's first part in fitting the minor hemistich to a single phrase and then drawing out the major one over several phrases. The line in the second part is set similarly but with

\footnotetext{
${ }^{18}$ Inversion of hemistichs in setting the decasyllable had already been tried in the refrains of B28 and B33.

${ }^{19}$ The plan here is a more flexible version of the technique in R8, which begins with a free sequence of three minorhemistich phrases which are answered with a strict isorhythmic sequence of three major hemistichs.

${ }^{20}$ The S-B-S rhythm is an important one in Machaut's polyphonic writing, appearing often in cantus and tenor voices. In addition to the three songs discussed here, see B1, B3, B5, B23, B25, B27, B28, B31, B34, R2, R3, R8, R9, R14, R17 and R20. See also the discussion of R8 in Wolfgang Dömling, Die mehrstimmigen Balladen, Rondeaux und Virelais von Guillaume de Machaut (Tutzing, 1970), 37-46.

${ }^{21}$ The others are 'Rose, lis' (R10) and 'Comment puet on' (R11).
} 
just two phrases to the major hemistich. A development from B35 is the inclusion of two octosyllabic phrases, which increase the variety of phrase lengths.

A formal element that is new to R13 is the use of complementary hemistichs to frame the parts. Each begins with a minor hemistich that is answered by a major hemistich in the same breve declamation at the end, the musical refrain. ${ }^{22}$ In the first part, several phrases are interpolated between the two; in the second part a single phrase, creating a condensed parodic version of the first. ${ }^{23}$ Splitting of the decasyllable creates a formal frame that holds the part together.

The relationship between B35 and R17 is not one of simple imitation. Where B35 aims for formality and balance, R13 aims for contrast. In B35, the phrases work in pairs, with symmetry in the body of the parts and then directed succession to achieve closure in the musical refrain. The different approaches to setting the lines are concentrated in distinct sections. The proportions of the overall form are balanced. In R13, the phrasal pairs are split: in the first part by a couple of contrasted phrases and then a sequence of minor hemistichs; in the second part by an octosyllabic phrase. A variety of phrases and of successions of phrases is sought. Different approaches to setting the lines are placed side by side. There is an exaggerated contrast in the scale of the two sections. The techniques of the ballade and rondeau are fundamentally the same; where they differ is in the formal use to which they are put. The adaptability of the technique is further apparent in the third song of this group. 'Quant je ne voy' (R21) is one of the three songs added to Machaut's output in Mach-G. Most likely Machaut's last rondeau, perhaps even his final composition, 'Quant je ne voy' draws heavily on both the materials and techniques of B35 and R13 to attain the aesthetic goal latent in their compositional process.

The 17 syllables of the poem are set to 76 breves of music, just over half of which are occupied by the statements of the musical refrain, and it is this extreme disparity between the short poem and its lengthy music that is the issue at stake. The phrasal form and distribution of the poem's few syllables across it are presented in Table 5.

\section{[INSERT TABLE 5 AROUND HERE]}

\footnotetext{
${ }^{22}$ A similar technique had been tried in B14, where an opening minor-hemistich phrase receives its complement right at the end.

23 'Machaut's “Parody” Technique,' Context 21 (2001), 5-20, at 12-13.
} 
The model of B35 is clear in the adoption of a similar structure: both parts comprise four phrases and are capped by a four-phrase musical refrain. The musical refrain in particular is structurally close to that of the ballade, with declamation in semibreves and an alternation of phrase-types; but the minor hemistichs of the ballade are expanded to octosyllables in the rondeau. There is a direct musical connection too, as the second phrase is an adaptation from the beginning of B35 (Example 6a).

\section{[INSERT EXAMPLE 6 AROUND HERE; NB: IT IS DIVIDED INTO TWO FILES.]}

There is also musical content from R13. ${ }^{24}$ The first phrase takes the musical refrain of that song with a breve extracted, turning a major hemistich in breve declamation to an octosyllable in semibreve declamation (Example 6e). The phrase is treated sequentially, in a way similar to that of the minor hemistichs in the first part of R13, to derive the third phrase; and it is restated with a further breve excised, creating a major hemistich with semibreve declamation, for the fourth phrase. The material of the musical refrain is thus derived from the other songs either directly or by straightforward manipulation.

Material from earlier in the song is borrowed as well. Like R13, R21 adapts the second phrase of B35's musical refrain (Example 6b). Here, expanded into an octosyllable, it becomes the second phrase of the second part; and from it the second phrase of the first part is parodically derived. ${ }^{25}$ The third phrase of the first part is derived from the medial phrase of the second part of R13 (Example 6d). The borrowing does not change the form of the phrase; but it does expand the phrase from five breves to six, a breve longer than the previous octosyllable and thus anticipating the length of the following major hemistich phrase (in breve declamation).

Despite the lack of decasyllables in the poem of R21, the structure of that line remains a crucial model for the music of the song, because of its complementary phrasing. The framing technique of R13 is deployed here on a larger scale. In the first part, a decasyllable is split between the first and final phrases, holding together a larger span than in the first part of R13. In the second part, two decasyllables are split: the first enclosing an octosyllable (creating a unit with the same form as the second part of R13); the second enclosing the bulk of the musical refrain. In R13, two of the phrases

\footnotetext{
${ }^{24}$ Alison Julia Bullock, 'The Musical Readings of the Machaut Manuscripts', Ph.D. diss., 2 vols (University of Southampton, 1997), vol. 1, 147; vol. 2, 46. See also David Maw, “"Trespasser mesure”: Meter in Machaut's Polyphonic Songs', Journal of Musicology 21 (2004), 46-126, at 97-99.

${ }^{25}$ Maw, 'Machaut's "Parody” Technique,' 17.
} 
are developed into octosyllables. This tendency is enhanced in R21, responding to the line-length of the poem; and although more than half of the phrases relate to the decasyllable, those that are minor hemistichs function also as half-lines to the octosyllables, as at the beginning of the song. To this end, the lines of the poem are conceived in tetrasyllabic hemistichs.

The song poses the questions why Machaut turned to an octosyllabic poem for his final rondeau and then having done so, why he retained so much decasyllabic phrasing. The answers to these questions are related. The octosyllabic poem supplied a rhythmically minimal frame from which to hang extended musical invention. The decasyllabic structure of paired phrasing was useful for selfsustaining musical composition as it supplied varied phrase lengths and a dynamic structure of complementary cadences (ouvert and clos). Moreover, it was rhythmically linked to the poetic form, as the octosyllable could be broken into tetrasyllabic halves, like a pair of minor hemistichs from decasyllables.

Machaut had already used decasyllabic phrasing to set octosyllables in 'Phyton' (B38) (Table 6). There was no accommodation of octosyllabic phrasing here; but the succession of two minor hemistichs at the beginning of the second part divided into tetrasyllabic halves. The setting of the other lines also relates to the decasyllable, breaking them after the sixth syllable like major hemistichs of the longer line. Doing this opens up the possibility for a melismatic extension of the seventh syllable, thereby freeing the musical form of its obligations to the poem.

\section{[INSERT TABLE 6 AROUND HERE]}

In B38, Machaut set the octosyllables almost as if they were decasyllables. Returning to octosyllables in R21, Machaut maintained the decasyllabic phrasing of B38 but developed it to include the octosyllabic phrasing tried in R13. This enabled suppler phrasing, a desirable quality when almost all of the attention in the song was to be focused on the music.

B35, R13 and R21 show Machaut creating a technique for developing phrasal form out of the hemistichal pairs of the decasyllable. The significance of such form lies in its consequences for the tonal development of the music. Each provides a certain temporal span for tonal actions that must coalesce in the form of the whole. In addition to their formal and material similarities, the three songs pursue a common tonality rooted in a C-F major tonic axis. The chords of $\mathrm{C}$ and $\mathrm{F}$ constitute 
the poles of the axis, and the body of all three songs is taken up with movements between them. ${ }^{26}$ Other chords supply tension, the most significant being those of D and E. The ouvert cadence is formed by arrival on $\mathrm{D}$ in all three songs as an incomplete progression from $\mathrm{F}$ to $\mathrm{C}$, completed in the continuation. All three songs make cadences on E minor as well. The importance of this chord is twofold: it is a leading chord to both $\mathrm{C}$ and $\mathrm{F}$, connecting the $\mathrm{C}$ and $\mathrm{F}$ chords both recursively to themselves and progressively to each other (Example 7); on this account, it focuses the ambiguity of direction within the tonality: it is certain that the E minor chord will lead to the tonic axis; but it is uncertain to which pole of that axis it will lead.

\section{[INSERT EXAMPLE 7 AROUND HERE]}

Comparison of harmonic reductions of the three songs (Example 8) helps to pinpoint the differences of procedure enabled by their respective phrasal forms:

\section{[INSERT EXAMPLE 8 AROUND HERE]}

- The formality of B35 is satisfying in its dialogue of poem and phrasing; but it presents a significant musical challenge for sustaining tonal tension through eight phrases in each part. Tension is created immediately, with a phrase that establishes the tonic axis before cadencing on the E minor leading-chord. The next phrase develops this premise, resolving the cadence to $\mathrm{C}$ and then back to $\mathrm{F}$ via the $\mathrm{E}$ minor chord, revealing its directional ambiguity. The following three phrases return to $\mathrm{C}$, with cadences on $\mathrm{E}$ minor in the second and third, introducing the musical refrain through an echo of the tonal tension of the first phrase. The sixth phrase resolves $\mathrm{E}$ minor back to $\mathrm{C}$, but then passes directly to $\mathrm{F}$ and from there to $\mathrm{D}$, preparing the ouvert. The seventh phrase resolves to $\mathrm{C}$ before reworking the progression from $\mathrm{F}$ to $\mathrm{D}$ at the ouvert. This becomes a clos phrase completing the progression to $\mathrm{C}$ at the reprise. The second part maintains $\mathrm{C}$ through the first three phrases. The fourth phrase returns to $\mathrm{F}$ in preparation for a rerun of the ouvert on $\mathrm{D}$, launching the musical refrain for the third time.

- R13 begins very similarly to B35, with a move from $\mathrm{C}$ to $\mathrm{F}$ leading to a cadence on $\mathrm{E}$ minor. It also employs a prolepsis of the ouvert cadence, here as early as the second phrase; but it is handled more subtly, treating D as an auxiliary to the E minor chord of the first cadence that is prolonged and finally resolved to $\mathrm{F}$ at the end of the third phrase. The fourth and fifth

\footnotetext{
${ }^{26}$ I presented a more extended account of this tonality in 'Machaut's Bifocal Tonality', paper read at the Plainsong and Medieval Music Conference, University of Bristol, 2002.
} 
phrases both work progressions from F to C; and the sixth returns to F to launch the ouvert phrase's move to D. All the tonal tension is focused in the extended first part. The second part serves as a resolution: each of its three phrases cadences on $\mathrm{C}$; but the middle one is differentiated through its weaker voice-leading.

- R21 returns to the large canvas of B35 but uses it differently. The tonic axis is prepared more gradually, focusing on $\mathrm{C}$ in the first two phrases and using a $\mathrm{B}$ minor leading chord in the first cadence. The third phrase introduces the $\mathrm{F}$ pole of the axis, returning to $\mathrm{C}$ at the cadence with the weaker voice-leading used in R13. A full cadence on F in the fourth phrase sets up the musical refrain, which initially returns to $\mathrm{C}$ before building tension in its second and third phrases by cadencing on $\mathrm{E}$ minor, the first leading to $\mathrm{C}$, the second to $\mathrm{F}$. The fourth phrase caps the tension of these cadences with the ouvert on D. The first phrase of the second part resolves the ouvert cadence to C, but the second replays the D cadence, prompting an emphatic riposte in the parallel 8-5 chords (D to C) of the third phrase's cadence. ${ }^{27}$ The cadence point itself epitomises the tonic axis through rapid movement between $\mathrm{C}$ and $\mathrm{F}$. A cadence on to $\mathrm{F}$ in the next phrase sets up the musical refrain as before. The final cadence of the refrain is reworked as a clos on C.

There is a progression of mastery and finesse through these three songs. B35 does not harness its effects altogether successfully, in part because of the intrinsic difficulties of ballade form: largescale handling and resolution of tonal tension is obviated by the need to release it through repetition of the first part with a modified final cadence. To compensate, too much tonal incidence is crowded into the opening phrases of B35, leaving little for the oultrepasse to accomplish. Whilst E minor is well used as a source of tonal tension, the continual return to the $\mathrm{D}$ chord undermines its effectiveness as a structural contrast with the tonic axis, particularly in the lead into the clos cadence of the first part. R13 adopts a similarly dense opening, but is more subtle in the use of D as a cadential chord. Tonal effect enhances the deliberately unbalanced form, with the short second part focusing exclusively on C cadences as a foil to the first. R21 is the most sophisticated of the three,

\footnotetext{
${ }^{27}$ Much has been made of the contrapunctus model of harmony in fourteenth-century polyphonic music, but it is important not to overlook other types of chord progression available to composers. The parallel harmony used here (and at cadences in B6 and R5, see Jennifer Bain, "'Messy Structure"? Multiple Tonal Centers in the Music of Machaut," Music Theory Spectrum, 30 (2008), 195-237, at 342) is found also in the first of the complete estampies of the Robertsbridge Codex (London, British Library, Add. MS 28850). Such harmony is commonplace in the compositions of the manuscript. It may relate to the harmonic practice noted by Jacques de Liège as deriving its name from the interval most used, such as 'fifthing' and 'fourthing' ('diapentizare vel quinthiare...quartare sive diatesseronare'). Roger Bragard, ed., Jacobi Leodiensis Speculum musicae, Corpus scriptorum de musica, ([Rome], 1973), vol. 3/7, 24. See Sarah Fuller, 'Discant and the Theory of Fifthing,' Acta Musicologica, 50 (1978), 241-75.
} 
integrating the successes of the two previous songs. It prepares the tonic axis more gradually than they, developing tonal tension towards the close of the first part and then releasing it through the second. When the D chord arrives at the ouvert, its structural dissonance has been carefully set up through the succession of cadences on $\mathrm{C}, \mathrm{F}$ and $\mathrm{E}$ minor. It is resolved in two stages through the first three phrases of the second part before the other tension, that of E minor, is then restated and resolved in the musical refrain.

In R21, Machaut succeeded both in sustaining the subtle tonal poise of the axial tonality and in carefully staging the elements of tension to place their arrival and resolution optimally for the balance of the form. ${ }^{28}$ To achieve this mastery, he needed to reuse a great deal of music material and reduce the poetic content to a minimum. The song is an essay in disposing given materials rather than in inventing new ones. Its aim is to deploy its musical ideas to the greatest effect on a large-scale. For this purpose, rondeau form was better suited, as its through-composed refrain resolved the ouvert into the newly composed music of the second part.

R4, R13 and R21 show Machaut exploiting rondeau form to enable the expression of pure, selfsustaining musical thought. Musical phrasing is in each case related to the poem set, but in an oblique way. To a significant extent it is free of the poems. The poems are thus pretexts for musical invention, not causes of it. Musical invention itself is the chief concern.

\section{Mimesis, abstraction and voice}

The idea of music and poetry, the two arts of song, constituting an imitation the one of the other had long been known to the Middle Ages. The condition was described by Guido of Arezzo in Chapter XVII of Micrologus, where he presented their relationship as a 'twofold melody': ‘... just as we very often see so much in verse the lines harmonious and answering one another, that we wonder at, as it were, a certain harmony of grammar. By which, if music were joined responding to them in a similar way, you would be doubly delighted by a twofold melody. ${ }^{29}$ Guido regards song as a

\footnotetext{
${ }^{28} \mathrm{R} 21$ does not represent the most extreme abstraction of music from poem. That point is achieved by R14, which is even a little longer. Like R21, its poem is built from a refrain of two octosyllabic lines. The music is concerned with the unique structural idea of a retrograde canon in its cantus, which imposes constraints quite unlike those governing any other piece by Machaut. The setting is melismatic, but the musical phrasing is derived from the octosyllable. The opening and closing phrases of both parts have the five-long duration of octosyllables in breve declamation (initial and terminal longs with six paired breves between). The full length of the refrain is 40 longs (that is, eight times the five longs of an octosyllable). Perhaps the first stage in the compositional process was to map out four octosyllables in each part. This established the frame phrasing at the beginning and end; in between phrase lengths were then varied within the timespan established.

29 ‘... sicut persaepe videmus tam consonos et sibimet alterutrum respondentes versus in metris, ut quamdam quasi symphoniam grammaticae admireris. Cui si musica simili responsione iungatur, duplici modulatione dupliciter
} 
twofold melody because the poetry imitates the music through harmonious arrangement of its parts. The poem and the music are two complete and independent entities; their elements are mutually complementary. Because both are held together by harmony, both constitute a kind of melody, and thus their combination is a twofold melody.

Similar thinking underpins Johannes de Grocheio's use of the concepts of consonance and concordance to explain aspects of poetic construction; ${ }^{30}$ and it forms the context for Eustache Deschamps's L'Art de dictier, a treatise on poetic composition in the formes fixes written fifteen years after Machaut's death. Its analysis of the formal properties of verse identifies the verbal art as a sort of natural music: 'these two musics are so consonant with one another that they can both be satisfactorily called music'. ${ }^{31}$ Music (in the usual sense) is presented as a technical activity that anyone can learn and thus artificial; poetry is the natural accomplishment of a talented few. The formal, sonic and consequently musical side of poetry is emphasised. A view of the art in line with the one set out in this article is proposed. Indeed, it would follow logically from the reckoning of poetry as natural music that music proper ('artificial' in Deschamps' view) would be the imitation of it. This is not in fact how the discussion proceeds, and it rather sets out the two arts in quite distinct terms, emphasising their material differences and separateness in song. The primary motivation for subsuming poetry to the category of music seems to be elevation of it to the higher status of the quadrivium. The natural-artificial distinction is useful to this end but lacks other consequences for the thinking. However, had the logic of the terms been pursued, it might have concluded that song was, as for Guido, a double music, simultaneously natural and artificial, poem and music.

Deschamps's implicit view of song is congruent with that of Machaut's compositional practice. Yet Machaut himself conceived it differently. Right at the beginning of the Prologue, he depicts himself being commissioned by Nature for the creation of poems. She endows him with the three gifts of meaning, rhetoric and music, and tells him that rhetoric shapes his thought as verse. ${ }^{32}$ If it is rhetoric

delecteris.' Jos. Smits van Waesberghe, ed., Guidonis Aretini Micrologus, Corpus scriptorum de musica 4 ([Rome], 1955), 188. [Is the English translation your own? If not, please cite it as well. DM - the translation is mine]

${ }^{30}$ Christopher Page, 'Johannes de Grocheio on secular music: a corrected text and a new translation,' Plainsong and Medieval Music, 2 (1993), 17-41, at 27-9.

31 ،...ces deux musiques sont si consonans l'une avecques 1'autre, que chascune puet bien estre appellée musique...' Gaston Raynaud (ed.), Oeuvres complètes d'Eustache Deschamps, 11 vols (Paris, 1891), 7:271.

32 'Retorique n'ara riens enferme/Que ne te envoit en metre et en rimer.' R. Barton Palmer, Guillaume de Machaut: The Fountain of Love (La Fonteinne Amoureuse) and Two Other Love Vision Poems (New York \& London, 1993$), 2$. 
that helps him turn ideas into verse, then it is the imitation of this rhetoric in music that helps him to turn verse into song. In this sense, song would comprise a twofold rhetoric.

As has been shown, the process of imitation, even as it seems to bring music and poetry close together causes them to become detached. It serves in part to bring out material and procedural differences between the two arts. Cadences, for example, can match rhymes, but they also serve as independent elements in the compositional thought and may be disposed differently. There is an alienation at work between the two arts, and it is intrinsic to Machaut's aesthetic stance not only that he recognised this but that he sought to develop it through dislocation of the imitative relationship. Such detachment of words and music attained a limit in R21. The lengthy music that set its rather short poem was not entirely liberated of verse. An imaginary poetic form moulded the phrasing of the music; but it did so almost without reference to the poem itself.

R21 shows how far Machaut could progress towards an art of pure musical invention through imitation of poetic procedures, achieving a setting in which the poem itself seems little more than a pretext for musical expression. This is not to say that the poem is entirely eradicated in the setting: the syllables are bunched at particular moments in the melody, and the words come into focus there. The setting does not, though, project the meaning of the poem, which is a description of the poet's suffering born of frustration:

Quant je ne voy ma dame n'oy, je ne voy riens qui ne m'anoye. Mes cuers font en moy comme noy, quant je ne voy ma dame n'oy. N'onques tel mal, par m'ame, n'oy pour mon oueil qui en plour me noie. Quant je ne voy ma dame n'oy, je ne voy riens qui ne m'anoye.
When I do not see or hear my lady, everything I see bothers me. My heart melts within me like snow, when I do not see or hear my lady. I assure you that I never suffered so much grief because of my eyes, which drown me in tears. When I do not see or hear my lady, everything I see bothers me.

The claustrophobic circularity of the rondeau form perfectly expresses the poet's state of mind. Yet there is no suffering in the music. The Prologue is explicit on the aesthetic position. It advocates a poetics of joie: music can never really express sad sentiment; its effect is always to make the listener happy, even when the poem expresses pain. Such is the case with R21: the music redeems the verse, turning it into joy. ${ }^{33}$ The tendency with verbal meaning as with verbal form is to

\footnotetext{
${ }^{33}$ David Maw, 'Machaut and the "Critical” Phase of Medieval Polyphony,' Music and Letters 87 (2006), 262-94 at 28994.
} 
abstraction through the music. Music acts in this way as the 'consolation of poetry'. ${ }^{34}$ In imitating the verse, the music goes beyond it and overpowers it, turning it into pure music. As Deschamps observed: 'each of these two [music and poetry] is pleasant to listen to by itself; and the one can be sung skillfully by voices without words' ${ }^{35}$

Machaut's poetry is well recognised for its exploitation of a protean voice: ${ }^{36}$ in particular, the pervasive courtly voice is often interrupted or subverted by a clerkly one, prone to commentary, reflection and detachment. The changes of declamation cultivated in Machaut's word setting effect switches of register. Sudden moves between the modus level setting of a chanson royale and the rapid syllabic delivery of a virelai or between melody and recitation are also shifts in voice: between the trouvère and the minstrel, or between the courtier and the clerk. The ballade was particularly amenable to such shifts (Example 9). Machaut's dissonant word setting subverted the voice of song from singularity into plurality, from specificity into universality. The song does not remain in a single perspective but aspires to occupy them all.

\section{[INSERT EXAMPLE 9 AROUND HERE]}

The distancing between music and poem that has been discussed effects a greater sense of depth in the setting. It is a symptom of artistry, of the educated clerk who reflects on and stylises his utterances. Tensions that are already apparent in the verse between claims to authenticity or immediacy of expression and the stylisations of poetic presentation reach a higher pitch in the songs, where the music continually deflects the utterance into the abstraction of formalised musical sound. This deflection is the process of the song, at once highly contrived through compositional forethought, and yet in performance locked to the aesthetic immediacy of musical time.

In the songs, the music goes beyond the words, abstracting them and turning them into music. It develops this music into its own substance. The extreme point of this transformation occurs in R14. The retrograde canon of the music and the poem's description of the musical construction have often been remarked. What is more important, though, is the crucial shift that takes place in the

\footnotetext{
${ }^{34}$ Elizabeth Eva Leach, 'Poet as Musician,' in Deborah McGrady and Jennifer Bain, ed., A Companion to Guillaume de Machaut (Leiden and Boston, 2012), 49-66 especially 58-63.

35 '....chacune de ces deux plaisant a ouir par soy; et se puet l'une chanter par voix et par art, sanz parole...' Raynaud, ed., Oeuvres complètes d'Eustache Deschamps, 7:272.

36 'The clerk, the lover, and the poetic craftsman are conflated into a single but multi-faceted poetic voice.' Kevin Brownlee, Poetic Identity in Guillaume de Machaut (Madison, 1984), 18.
} 
song. The 'je' of the poem is no longer the courtly subject but music itself. ${ }^{37}$ The voice of song is completely subsumed by its musical expression. The music sings itself. What results is pure music.

${ }^{37}$ See Anne Stone, 'Music Writing and Poetic Voice in Machaut: Some Remarks on B12 and R14,' in Leach ed., Machaut's Music, 125-38, at 136-37. 